\title{
Phytochemical and Molluscicidal activity of Mikania glomerata Sprengel (Asteraceae) in Different Lifestages of Subulina octona (Mollusca, Subulinidade)
}

\author{
Bruna Aparecida de Souza ${ }^{1,2}$, Lidiane Cristina da Silva ${ }^{2}$, Evelyn Durço Chicarino ${ }^{2}$ and \\ Elisabeth Cristina de Almeida Bessa ${ }^{2}$ \\ ${ }^{1}$ Pós-graduação em Ciências Biológicas; Comportamento e Biologia Animal; Universidade Federal de Juiz de \\ Fora; Juiz de Fora - MG - Brasil. ${ }^{2}$ Museu de Malacologia Prof. Maury Pinto de Oliveira; Universidade Federal de \\ Juiz de Fora; Juiz de Fora - MG - Brasil
}

\begin{abstract}
The objective of this work was to study the molluscicidal activity of aqueous extract of Mikania glomerata on the land snail Subulina octona and to assess the changes caused on the snail's fecundity, growth, hatchability and the offspring produced after exposure. Eggs, newly hatched and 30 day old snails were exposed to the sublethal concentration of M. glomerata extract for 24 and $48 \mathrm{~h}$ and the observations were made for 120 days. The presence of tannins, flavonoids and saponins were shown by phytochemical tests. The extract reduced significantly the hatchability and the survival of the offspring hatched from the exposed eggs. The eggs exposed for $48 \mathrm{~h}$ presented lower hatchability rates. There was a reduction on survival and growth of newly hatched and 30-days old snails exposed to the extract. These results indicated that the aqueous extract of M. glomerata could be applied as an alternative molluscicide for the control of this snail species efficiently.
\end{abstract}

Key words: Land snail, guaco, molluscicidal, toxicity, control

\section{INTRODUCTION}

The land snail Subulina octona (Subulinidae) is widely distributed in Brazilian territory and is generally found in damp and shaded places such as vegetable gardens and gardens (Araújo and Bessa 1993). This species can be a problem for public health because it acts as an intermediate host of parasites that infect humans and domestic animals such as Postharmostomum gallium (Witenberg 1923); Alicata (1940) and Duarte (1980); Platynosomum illiciens (Braum 1901) Maldonado (1945); Tanaisia bragai (Santos 1934) Brandolini et al. (1997); Angiostrongylus vasorum (Baillet) (Bessa et al. 2000) and can be a crop pest in high densities. Due to this reason, it is necessary to control this species. Moreover, S. octona represents a good biological model for laboratory studies, due to some characteristics of its lifecycle such as high rates of reproduction and hatchability, fast sexual maturity, short incubation period (Bessa and Araújo 1995) and homogeneous growth (D'ávila and Bessa 2005) making easy to analyse the products and/or extracts with potential molluscicidal activity.

Synthetic molluscicides currently used cause contamination to environment due to their high toxicity (Gasparotto et al. 2005). Therefore, the World Health Organization recommends the use of plant molluscicide because of their lower toxic and

*Author for correspondence: brunny_souza@yahoo.com.br 
residual effects (WHO 1983). Niclosamide (2,5dichloro-4-nitrosalicylanilide) is the only synthetic molluscicide recommended by WHO (2002). However, its high cost and difficult formulation make its use difficult.

The species Mikania glomerata Sprengel (Asteraceae), popularly known as "guaco" (Rocha et al. 2008) is an herbaceous creeper (Neves and Sá 1991) widely distributed in Brazil and commonly used in folk medicine to treat respiratory diseases (Santos 2005).This plant presents active principles in its chemical composition such as flavonoids, saponins and tannins, all with biocidal activity, including against snails (Neves and Sá 1991; Lima and Biasi 2002; Taleb-Contini 2006; Haida et al. 2007; Filho 2010). Saponins are chemically classified as steroidal glycosides, or polycyclic terpenes, which comprise a hydrophilic glycoside and a lipophilic (triterpene, or steroid) moiety that are responsible for its capacity to reduce the surface tension and foaming in aqueous solutions. Flavonoids are an important class of polyphenols found in the plants, which present antioxidant properties Tannins are phenolic compounds found naturally as esters, or heterosides, soluble in water and in polar organic solvents. They are classified in two groups based on their structural types: hydrolysable tannins and condensed tannins (Simões et al. 2010).

The aim of this study was to assess the effects of $\mathrm{CL}_{50}$ of the aqueous extract of $M$. glomerata on different life stages of $S$. octona exposed for 24 and $48 \mathrm{~h}$.

\section{MATERIALS AND METHODS}

The eggs, newly hatched and 30 day old snails used in this study were obtained from a colony maintained at the Snail Biology Laboratory of Prof. Maury Pinto de Oliveira Malacology Museum at Juiz de Fora Federal University (latitude: $21^{\circ} 45^{\prime} 13^{\prime \prime} \mathrm{S}$; longitude: $43^{\circ} 21^{\prime} 19^{\prime}$ ' W; 678 $\mathrm{m}$ altitude). The snails were kept in plastic terrariums ( $9 \mathrm{~cm}$ diameter, $6 \mathrm{~cm}$ length) containing $50 \mathrm{~g}$ of moistened sterilized mulch $\left(120^{\circ}\right.$ for $\left.1 \mathrm{~h}\right)$ and closed with cotton cloth and rubber bands. In all the tests, the terrariums were moistened with tap water and the animals were fed with poultry feed enriched with calcium carbonate according to Bessa and Araújo (1995).

The leaves of M. glomerata were collected in January, 2011 from a vegetable garden in São
Benedito in Juiz de Fora city, MG (S 21 ${ }^{\circ} 44^{\prime}$ 985' '; HO 43 $19^{\circ}$ ' 894'"; 831 m of altitude). One exsiccate was added at the herbarium Leopoldo Krieger at Federal University of Juiz de Fora under register CESJ 58.407. The leaves were washed and dried at room temperature for 10 days. The aqueous extract of the aerial parts was obtained by cold static soaking of the leaves in distilled water for $72 \mathrm{~h}$ and the solution was filtrated. The sublethal concentration $\left(\mathrm{LC}_{50}\right)$ was calculated for adult snails $(45 \mathrm{mg} / \mathrm{mL})$ and the same dose was used in all the tests of hatchability and survival. The $\mathrm{LC}_{50}$ was calculated by the Probit analysis using the BioStat 2008, version 2.5 program.

\section{Saponins analysis}

Saponins for the analysis were made by a decoction of $2.0 \mathrm{~g}$ dried plant in $10 \mathrm{~mL}$ of distilled water for three minutes. After cooling and filtration of this solution, $5.0 \mathrm{~mL}$ of the filtrate was into a test tube and shaken vigorously for 15 seconds and left to rest for $15 \mathrm{~min}$. The formation of persistent foam after the settling time and addition of three drops of hydrochloric acid showed the presence of saponins. For semiquantitative analysis, $1.0 \mathrm{~g}$ of the dry plant was decocted in $100 \mathrm{~mL}$ of distilled water for $30 \mathrm{~min}$. The solution was filtered and the filtrate was tested for was added in 10 test tubes $(16 \mathrm{~cm}$ height and $16 \mathrm{~mm}$ diameter, numbered 1 to 10 ) in increasing amounts and supplemented with distilled water to $10 \mathrm{~mL}$ The identification of saponins and the foaming index were determined according to WHO (1992) and Farmacopéia Brasileira (2010).

\section{Flavonoids analysis}

Flavonoids were identified by the colorimetric analysis with $10 \%$ sodium hydroxide, with a decoction of $5.0 \mathrm{~g}$ of the dried plant in $100 \mathrm{~mL}$ of distilled water during $15 \mathrm{~min}$, followed by filtration. The presence of flavonoids was confirmed by a yellowish coloration (Mouco et al. 2003).

\section{Tannins analysis}

A decoction was made with $10 \mathrm{~g}$ of $M$. glomerata in $250 \mathrm{~mL}$ of distilled water during $15 \mathrm{~min}$. After cooling, the extract was filtered and the aqueous fraction was used for the test. An agar solution (Merck) was prepared at $2.5 \%$ in distilled water previously heated. The extract $(2.0 \mathrm{~mL})$ was taken in a test tube to which two drops of dilute 
hydrochloric acid were added. In another test tube, the same amount of extract and acid was taken and the agar solution was added drop by drop. The presence of tannins was confirmed by the turbidity of the aqueous extract. To differentiate the class of tannins (condensed, or hydrolysable), a colorimetric test with $2 \%$ ferric chloride $\left(\mathrm{FeCl}_{3}\right)$ was used Stiasny (Doat 1978). For this, a decotction mixing $10 \mathrm{~g}$ in $250 \mathrm{~mL}$ distilled water for $30 \mathrm{~min}$ and filtering. An aliquot of $100 \mathrm{~mL}$ of this extraction was transferred to a $500 \mathrm{~mL}$ beaker and $15 \mathrm{~mL}$ of reactive Stiasny was added $(5.0 \mathrm{~mL}$ of concentrated hydrochloric acid and $10 \mathrm{~mL}$ of $10 \%$ formaldehyde) prepared minutes before the reaction. The solution was left to stand for $24 \mathrm{~h}$ and the precipitate obtained after filtration was dried in an oven at $101 \pm 2{ }^{\circ} \mathrm{C}$ until constant weight, which was the number of Stiasny ( $\mathrm{g}$ quantity of condensed tannins in the aliquot). For this test, the analysis was done in triplicate.

\section{Analysis of hatchability after the exposure of eggs for 24 and $48 \mathrm{~h}$}

Sixty eggs were distributed in four groups (15 eggs/ group). The assays were conducted at room temperature and the relative air humidity was daily measured $\left(21-24^{\circ} \mathrm{C}\right.$ and $82 \%$ of relative air humidity). The eggs were sprayed using $20 \mathrm{~mL}$ of the extract and left for 24 and $48 \mathrm{~h}$. Control groups composed of the same number of eggs sprayed with $20 \mathrm{~mL}$ of distilled water and left for the same time period. Then the eggs were transferred to terrariums with the same measurements and lined with previously sterilized mulch and moistened with tap water. The eggs were observed daily to assess the hatchability during 30 days.

\section{Survival of the offspring hatched from exposed eggs}

The hatched juveniles were kept in the same conditions as described above. Snails were fed ad libitum with poultry feed enriched with calcium carbonate (3:1 proportion). The mortality and time required to reach the maturity were assessed every three days during 120 days.

Effects of the $\mathrm{LC}_{50}$ on growth, survival and reproduction on newly hatched and 30-days old Subulina octona exposed for 24 and $48 \mathrm{~h}$ to the aqueous extract of $M$. glomerata

For this assay, 40 newly hatched and 30-days old snails were used with mean size of $2.03 \mathrm{~mm} \pm$ $0.24 \mathrm{~mm}$ (newly hatched) and $6.00 \mathrm{~mm} \pm 0.58 \mathrm{~mm}$ (30-days old juveniles). The snails were distributed in four groups (10 eggs/ group) and kept in plastic terrariums lined with previously sterilized mulch, where was pulverized with 20 $\mathrm{mL}$ of the extract. The control groups comprising the same number of snails received only distilled water. The terrariums were closed with cotton cloth and an elastic rubber to avoid the escape of the snails. After the exposure period, the snails were transferred to other terrariums and fed as described before.

The growth was determined by monthly measurements of shell length using a caliper rule Kanon (Mardened Stainless 1/28 in. 1/20 mm). To assess the mortality, analysis were conducted every three days during 120 days by direct observation of the snails and the dead snails were removed from terrariums. The sexual maturity was assessed with the same frequency and determined by the presence of eggs in the uterus, seen through the shell (D'ávila and Bessa 2005).

\section{Statistical analysis}

The Kruskal-Wallis and the Student-NewmanKeuls, both with significance level of $5 \%$, were applied to compare the hatches means. Mortality rates and the growth of the snails exposed to the extract were calculated with the BioEstat software, version 5.0. The survival curves were prepared using the Origin software version 6.0.

\section{RESULTS}

\section{Phytochemical analysis}

The aqueous extracts of $M$. glomerata showed a yellowish color that changed into red after the addition of sodium hydroxide confirming the presence of flavonoids. The test with agar solution to confirm the presence of tannins was positive. The moss green coloration observed after the addition of ferric chloride confirmed the presence of condensed tannins, which was also confirmed by the Stiasny test. The results of these tests are presented on Table1. Results showed the presence of saponins and the foam index was 100 . 
Table 1 - Tannins content (expressed in $\mathrm{g} / 100 \mathrm{~g}$ of the dried plant) in the aqueous extract of Mikania glomerata, the percentage of tannins in the extract and in the plant.

\begin{tabular}{ccccc}
\hline Specie & $\begin{array}{c}\text { Tannins } \\
\text { mass in } \\
\text { the plant } \\
\left(\mathbf{g}^{*} \mathbf{1 0 0}^{-1}\right)\end{array}$ & $\begin{array}{c}\text { Total in } \\
\text { come of } \\
\text { tannins } \\
(\%)\end{array}$ & $\begin{array}{c}\text { Total } \\
\text { tannins in } \\
\text { the } \\
\text { extract }(\%)\end{array}$ & $\begin{array}{c}\text { Total } \\
\text { tannins }(\%) \\
\text { in the }\end{array}$ \\
\hline $\begin{array}{c}\text { M. } \\
\text { glomerata }\end{array}$ & $1.77 \pm 0.64$ & 13.58 & 15.16 & 2.05 \\
\hline
\end{tabular}

\section{Analysis of hatchability after the exposure of} eggs for 24 and 48 hours

The analysis demonstrated that the $M$. glomerata extract influenced negatively the hatchability of the eggs exposed for $24 \mathrm{~h}(\mathrm{H}=10.9357 ; \mathrm{p}=0.001)$ and $48 \mathrm{~h}(\mathrm{H}=21.9613 ; \mathrm{p}<0.0001)$. The exposure time also influenced the hatching rates, with hatchability significantly lower on the higher exposure time $(\mathrm{H}=4.536 ; \mathrm{p}=0.0343)$. There was no difference between the hatching means for the control groups in both time period $(\mathrm{H}=0.0625$; $\mathrm{p}=0.8026$ ) with a percentage of 98.3 and $94.6 \%$ for the groups exposed for 24 and $48 \mathrm{~h}$, respectively (Table 2).

\section{Survival of the offspring hatched from the exposed eggs}

The survival of snails hatched from the eggs exposed to the extract were significantly lower when compared to the control groups $(24 \mathrm{~h}$ : $\mathrm{H}=8.1270, \mathrm{p}=0.0047 ; 48 \mathrm{~h}(\mathrm{H}=10.5058 ; \mathrm{p}=0.0023)$ (Fig. 1). Although the hatching means for the groups treated with $M$. glomerata for $24 \mathrm{~h}$ had been higher when compared to $48 \mathrm{~h}$, the survival of hatched snails were different, being higher for $48 \mathrm{~h}$ group than for $24 \mathrm{~h}$ group $(\mathrm{H}=5.3333$; $\mathrm{p}=0.0341$ ). No signifcant difference was observed on the survival percentage of the snails from the control groups for both time period of exposure $(\mathrm{H}=8.3333 ; \mathrm{p}=0.2612)$ with 86.4 and $89.5 \%$ for 24 and 48 h groups, respectively (Fig. 1).

There was no onset of sexual maturity on the exposed and control groups during the observation period.

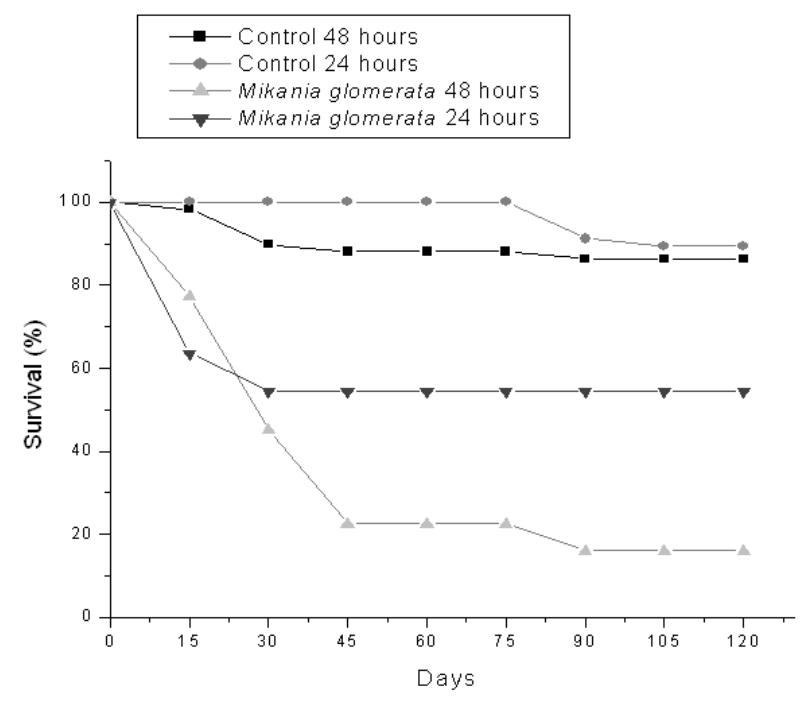

Figure 1 - Survival of the offspring of Subulina octona, hatched from eggs exposed to the aqueous extract of Mikania glomerata, for two exposure period ( 24 and 48 hours), observed for 120 days.

Table 2 - Hatchability of Subulina octona exposed to the aqueous extract of Mikania glomerata for 24 and 48 hours observed for 30 days (mean, standard deviation, range of variation and hatchability percentage).

\begin{tabular}{ccccc}
\hline \multicolumn{2}{c}{ Groups } & $\begin{array}{c}\text { Hachability } \\
\mathbf{X} \pm \text { SD }\end{array}$ & Range of varitation & Hatchability percentage (\%) \\
\hline \multirow{6}{*}{ Control } & 24 hours & $14.75 \pm 0.43^{\mathrm{a}}$ & $(14-15)$ & 98.3 \\
& 48 hours & $14.25 \pm 1.29^{\mathrm{a}}$ & $(12-15)$ & 94.6 \\
\multirow{3}{*}{ Exposed } & 24 hours & $7.75 \pm 4.08^{\mathrm{b}}$ & $(1-11)$ & 51.6 \\
& 48 hours & $2.00 \pm 1.47^{\mathrm{c}}$ & $(1-5)$ & 18.3 \\
\hline
\end{tabular}

$\overline{\mathrm{a}, \mathrm{b}, \mathrm{c}}=$ means followed by different letters are significantly different according to the Kruskal-Wallis test $(\mathrm{p}<0,05)$. The average number of eggs is the sum of the number of eggs divided by the total number of live molluscs.

Effects of the $\mathrm{LC}_{50}$ on growth, survival and reproduction of newly hatched Subulina octona exposed for 24 and 48 hours to the extract The survival of newly hatched snails exposed to the aqueous extract was lower in comparison to the control group ( 24 hours: $\mathrm{H}=6.0541 ; \mathrm{p}=0.0209$; 48 hours: $\mathrm{H}=6.137$; $\mathrm{p}=0.0209$ ) (Fig. 2). Exposed groups reached $100 \%$ of mortality at the end of 75 days. 


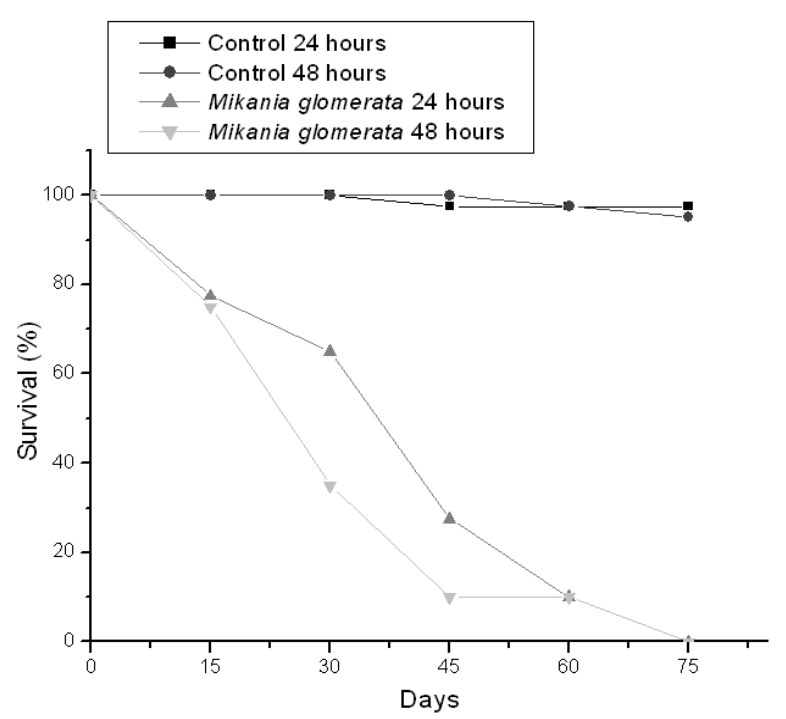

Figure 2 - Survival of newly hatched Subulina octona exposed to the aqueous extract of Mikania glomerata, for 24 and 48 hours, observed for 75 days after exposure.

At 60 days, the growth of the exposed groups differed from the groups on both the exposure periods $(24 \mathrm{~h}: \mathrm{H}=8.61, \mathrm{p}=0.0034 ; 48 \mathrm{~h}: \mathrm{H}=$ $4.1951, \mathrm{p}=0.0408)$. No significantly difference was observed on the growth of $S$. octona exposed to the extract for both the periods $(\mathrm{H}=0.2727$, $\mathrm{p}=0.6015$ ). Exposed groups did not differ between each other for exposure periods $(\mathrm{H}=8.1028$, $\mathrm{p}=0.0045$ ). The average size in the treated groups was $8.06 \pm 0.55$ and $8.2 \pm 1.78 \mathrm{~mm}$ for the 24 and 48 $\mathrm{h}$, respectively; for the control group, this mean was $9.53 \pm 0.72 \mathrm{~mm}$ for the $24 \mathrm{~h}$ and $10.01 \pm 1.71$ in the $48 \mathrm{~h}$. The maturity was attained by the exposed groups for both exposure times. Only $13 \%$ of the snails from the control groups exposed for $24 \mathrm{~h}$ and $37 \%$ of snails exposed for $48 \mathrm{~h}$ reached sexual maturity at the end of the 75 days of observations.

Effects of the $\mathrm{LC}_{50}$ on growth, survival and reproduction on 30 day old Subulina octona exposed for 24 and 48 hours to the treatments.

There was no mortality during the first hours after the exposure. The groups treated for $48 \mathrm{~h}$, the first death occurred on the third day after the exposure. At the end of the $8^{\text {th }}$ week, the mortality rate was $100 \%$ for this group. The survival of the snails exposed for $24 \mathrm{~h}$ was significantly lower compared to the control groups exposed to the same time period $(\mathrm{H}=5.6 ; \mathrm{p}=0.0209)$. These results were similar to the groups exposed for $48 \mathrm{~h}(\mathrm{H}=6.0541$; $\mathrm{p}=0.0139$ ). The survival percentage of the exposed and control groups are shown in Figure 3. There was no significant differences on the survival between the groups exposed for 24 and $48 \mathrm{~h}(\mathrm{H}=1$; $\mathrm{p}=0.3173$ ), which was probably due to the high percentage of mortality for both the groups. Figure 3 also showed that the survival at the end of 15 days in groups exposed for $48 \mathrm{~h}$ was about $20 \%$. To reach this same survival rates, the $24 \mathrm{~h}$ groups took 80 days.

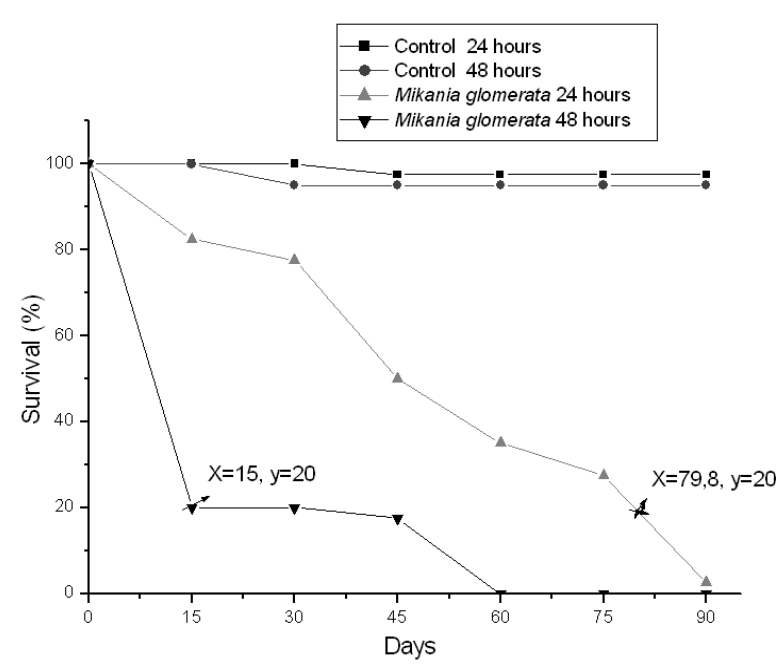

Figure 3 - Survival of $30^{\text {th }}$ day old Subulina octona exposed to the aqueous extract of de Mikania glomerata for 24 and 48 hours observed for 90 days after exposure. Points in axis $\mathrm{X}$ and $\mathrm{Y}$ marked to evaluate the efficiency and time of action on both 24 and 48 hours exposure period.

The growth in groups exposed for $24 \mathrm{~h}$ was monitored until the $60^{\text {th }}$ day, while for groups exposed for $48 \mathrm{~h}$ this was until the $30^{\circ}$ th day as by his time the mortality was $100 \%$. The growth of control groups was significantly higher when compared to the groups exposed for the same time period ( $24 \mathrm{~h}: \mathrm{H}=6.9585, \mathrm{p}=0.0084 ; \mathrm{H}=11.6639$, $\mathrm{p}=0.0006$ ). The average size in the exposed groups was $7.52 \pm 1.11 \mathrm{~mm}$ and $8.01 \pm 1.08 \mathrm{~mm}$ for the groups exposed for 24 and $48 \mathrm{~h}$, respectively. This mean was $9.13 \pm 1.40 \mathrm{~mm}$ for the $24 \mathrm{~h}$ and $10.82 \pm 1.99 \mathrm{~mm}$ for the $48 \mathrm{~h}$ for the control groups. Only $9 \%$ of the living snails from the groups exposed for $24 \mathrm{~h}$ reached the sexual maturity at the end of the observation period. For the $48 \mathrm{~h}$ group no sexual maturity was seen. This was 36 and $52.6 \%$ for the control groups exposed for 24 and $48 \mathrm{~h}$, respectively. The age (days) of snails at the 
reach of maturity was: $24 \mathrm{~h}: 67.4 \pm 6.04 ; 48 \mathrm{~h}$ : $59.6 \pm 3.38$ for the control groups and 24 h: $87.0 \pm 0$ for the exposed groups.

\section{DISCUSSION}

The hatching rates obtained for the control groups corroborated with the data obtained by Bessa and Araújo (1995) who reported a rate of $94.8 \%$ on the viability of the eggs for the species. The low hatching rates are important for the control of snails because if the number of hatched snails is low, the lower would be the adult population with reproductive potential. The inactiveness of some extracts in snails eggs have been questioned by some authors (Pereira et al. 1978; Souza et al. 1992; Magalhães 2003; Leyton et al. 2005). According to Lemma and Yau (1974), the low efficiency of molluscicides in eggs is probably due to their high molecular weights that hinder the passing of the molluscicides through the membrane that the egg has. The aqueous extract of $M$. glomerata affected the hatchability of $S$. octona, which suggested that the molecular structure of the active principles responsible for the toxic effects were simplified structure with a lack of ramifications, making easy the penetration in the pores of the membrane that enveloped the embryo. According to Figure 3, the efficiency of the extract related to the time of action in 30-days old snails was higher in the groups exposed for 48 h. This showed that the higher exposure period was related to high mortality of the snails, and therefore to a successfully control.

Although the treated and controls molluscs were at the same temperature, this could have influenced the achievement of sexual maturity of newborns $S$. octona since these could already be weakened by the exposure to extract. According to Furtado et al. (2004), the influence of temperature on the life cycle of land snails influences the reproduction, growth and the behavior. Ferreira (2009) observed the reaching of sexual maturity of 30-days old snails of the same species exposed to a caffeine solution with 105. Bessa and Araújo (1995) found the reach of sexual maturity in S. octona from 38 to 50 days after the birth; however, this study was conducted at higher temperatures. The changens in the growth of newly hatched and 30-days old snails resulted by the $M$. glomerata extract in $S$. octona could be an important result to control this snail. D'ávila and Bessa (2005) observed that the shell length of $S$. octona was directly related with the uterus size and snail's fecundity. The exposure time influenced the intensity of the effects on different life stages of this species. This indicated a stability of these active principles until $48 \mathrm{~h}$ after the application contributing to an increase in the efficiency of the extract.

To control a population of the snails with epidemiological importance, aquatic or terrestrial, it is necessary to find the alternative molluscicides with easy preparation and application that show toxicity at low concentrations. It should be toxic for several life stages of the snails, selective and harmless for humans and environment (WHO, 1965; Singh et al. 1996; Ministério da Saúde 2008).

The interferences caused by the exposure to $\mathrm{LC}_{50}$ of the extract obtained from $M$. glomerata on different life stages of the snailsvcould be due to the presence of saponins and tannins that easily dissolved in the water (Simões et al. 2010) and could penetrate through the pores of the thin calcite layer that enveloped the embryo. The probable mechanism of the action of hypocholesterolemic saponins is related to its capacity to cause cellullar lyses and complexation with steroids, resulting in the biocidal action of these compounds (Simões et al. 2010). Tannins are polyphenols, containing several hydroxyl groups that make possible thir complexation with proteins, causing precipitation and as a consequence, its inactivation. This characteristic can explain the action of tannins. Flanonoids may act by inhibiting the detoxification system of the snail. Silva (2007) found changes in the enzyme cytochrome P450 in land snail Cantareus aspersus (Müller) (Helicidae) exposed to tobacco leaves, Nicotiana tabacum (Solanaceae). This enzyme is part of an ancient family of proteins and acts in detoxification process degrading various xenobiotics and turning them into easily excreted molecules. These compounds can act synergistically, be additive or even making easier the absorption of another compound, intensifying the lethal effects in the snails. Plants with higher content of tannins, saponins and flavonoids may be more efficient in the control of molluscs

In Brazil, there are few studies on molluscicides to control the land snails. Most of the studies are focused on aquatic snails, especially Biomphalaria involved in the transmission of Schistosoma mansoni (Mello-Silva et al. 2006a; Mello-Silva et al. 2006b; Bardón et al. 2007; Xavier et al. 2010). 
Therefore, more comprehensive studies of molluscicidal compounds in plant species of Brazilian flora directed to land snails are needed. These results demonstrated that the $M$. glomerata extract affected significantly the different life stages of $S$. octona, affecting the hatch and survival of the juveniles. The application of the extract also reduced the survival and growth means of newly hatched and 30-days old snails. Results also showed a direct relation between the hatchability and time of exposure of the eggs to the extract and that the exposure of the snails to the extract influenced the survival along the time. These results, allied to the easy preparation of the extract, low cost of application, could make the aqueous extract of $M$. glomerata an alternative molluscicidal efficient in the control of this species.

\section{CONCLUSION}

Mikania glomerata is a largely distributed plant of easy cultivation that possessed active principles with molluscicidal activity. Due to the solubility of the these principles in water, the process of their extraction could be environmentally-friendly and cheap. The results obtained in this study could guide other studies for controlling other snail species with epidemiological importance, which could be used on crop pests.

\section{ACKNOWLEDGMENTS}

We thank Coordenação de Aperfeiçoamento de Pessoal de Nível Superior (CAPES) for the fellowship.

\section{REFERENCES}

Alicata JE. The life cicle of Postharmostomum gallinum, the cecal flucke of poutry. J Parasitol. 1940; 26: 135-146.

Araújo JLB, Bessa ECA. Moluscos de importância econômica do Brasil. II Subulinidae, Subulina octona (Bruguiére) (Mollusca, Gastropoda, Pulmonata, Stylommatophora). Rev Bras Zool. 1993; 10: 489497.
Bardón AS, Borkosky S, Ybarra MI, Montanaro S, Cartagena E. Bioactive plants from Argentina and Bolivia. Fitoterapia. 2007; 78: 227-231.

Bessa ECA, Araújo JLB. Oviposição, tamanho de ovos e medida do comprimento da concha em diferentes fases do desenvolvimento de Subulina octona (Bruguiére) (Pulmonata, Subulinidae) em condições de laboratório. Rev Bras Zool. 1995; 12: 647-654.

Bessa ECA, Lima WS, Daemon E, Cury MC, Araújo JLB. Desenvolvimento biológico de Angiostrongylus vasorum (Baillet) Kamensnky (Nematoda, Angiostrongylidae) em Subulina octona Bruguiere (Molusca, Subulinidae) em condições de laboratório. Rev Bras Zool. 2000; 17: 29-41.

Brandolini SPB, Amato S, Pereira AA. Relacionamento de Tanaisia bragai (Digenea, Eucotylidae) e seu hospedeiro intermediário, Subulina octona (Gastrópoda, Subulinidae) sob condições experimentais. Parasitol al dia.1997; 21: 1-7.

D’ávila S, Bessa ECA. Influência do substrato sobre o crescimento de Subulina octona (Brugüière) (Mollusca, Subulinidae), sob condições de laboratório. Rev Bras Zool. 2005; 22: 205-211.

Doat J. 1978. Les Tanins dans les bois Tropicaux. Revue Bois et Florêt des Tropiques. Nogent. 1978. 182: 37-35.

Duarte MJF. O ciclo evolutivo de Posthamostomun gallinum Witenberg, 1923, no Estado do Rio de Janeiro, Brasil (Trematoda, Brachylaemidae). Rev Bras Biol. 1980; 40:783-809.

Farmacopéia Brasileira. Agência Nacional de Vigilância Sanitária, Vol. I, 5º edição, Brasília, 2010.

Ferreira P, Soares GLG, D'ávila S, Bessa ECA. The influence of caffeine and thymol on the survival, growth and reproduction of Subulina octona (Brugüière, 1789) (Mollusca, Subulinidae). Braz Arch Biol Technol. 2009; 52: 945-952.

Filho RB. Contribuição da Fitoquímica para o desenvolvimento de um País Emergente. Quim Nova. 2010; 33: 229-239.

Furtado MCV, Bessa ECA, Castanõn MCM. Ovoteste de Bradybaena similaris (Férussac, 1821) (Mollusca, Xanthonychidae): histologia e produção de gametas. Rev Bras Zoociênc. 2004; 6: 7-17.

Gasparotto Jr. A, Brenzan MA, Piloto IC, Cortez DAG, Nakamura CV, Filho BPD, et al. Estudo Fitoquímico e avaliação da atividade moluscicida do Calophyllum brasiliense CAMB (Clusiaceae). Quim Nova. 2005; 28: 575-578.

Haida KS, Parzianello L, Werner S, Garcia DR, Inácio CV. Avaliação in vitro da atividade antimicrobiana de oito espécies de plantas medicinais. Arq Ciência e Saúde Unipar. 2007; 11: 185-192. 
Lemma A, Yau P. Studies on the molluscicidal properties of endod (Phytolacca dodecandra), III. $J$ Ethiopian Medical. 1974; 12: 109-114.

Leyton V, Henderson TO, Mascara D, Kawano T. Atividade moluscicida de princípios ativos de folhas de Lycopersicon esculentum (Solanales, Solanaceae) em Biomphalaria glabrata (Gastropoda, Planorbidae). Iheringia, Sér Zool. Porto Alegre 2005; 95: 213-216.

Lima NP, Biasi LA. Estaquia semilhenhosa e comparação de metabólitos secundários em Mikania glomerata Sprengel e Mikania laevigata Schultz Bip. ex Baker. Sci Agríc. 2002; 1-2: 113-132.

Magalhães AF, Tozzi AMGA, Santos CC, Serrano DR, Zanotti-Magalhães EM, Magalhães EG, et al. Saponins from Swartzia langsdorffii: Biological Activities. Mem Inst Oswaldo Cruz. 2003; 98: 713718.

Maldonado JF. The life cicle of Tamerlania bragai Santos, 1934 (Eucolydae) a kidney of domestic pigeons. J Parasitol. 1945; 31: 306-314.

Mello-Silva CC, Vasconcellos MC, Pinheiro J, Rodrigues MLA. Physiological changes in Biomphalaria glabrata Say, 1818 (Pulmonata: Planorbidae) caused by sub-lethal concentrations of the latex of Euphorbia splendens var. hislopii N.E.B (Euphorbiaceae). Mem Inst Oswaldo Cruz. 2006b; 101: 3-8.

Mello-Silva CC, Lima M, Pinheiro J, Bezerra JCB, Rodrigues MLA. Alterações fisiológicas em Biomphalaria glabrata tratadas com extrato bruto de Solanum malacoxylon. Cienc Anim. 2006a; 16: 61-70.

Ministério da Saúde. Vigilância e Controle de Moluscos de Importância Epidemiológica. Diretrizes técnicas: Programa de Vigilância e Controle da Esquistossomose (PCE). $2^{\circ}$ edição, Brasília, 2008.

Mouco GB, Bernardino MJ, Cornélio ML. Controle de Qualidade de Ervas Medicinais. Biotecnologia Cienc Desenvolv. 2003; 31:68-73.

Neves LJ, MFA Sá. Contribuição ao estudo das plantas medicinais Mikania glomerata Sprengel. Rev Bras Farm. 1991; 72: 42-47.

Pereira JP, Souza CP, Mendes NM. Propriedades moluscicidas da Euphorbia cotinifolia L. Rev Bras Pesq Médica e Biológica. 1978; 11: 345-351.

Rocha L, Lucio EMA, França HS, Sharapin N. Mikania glomerata Spreng: Desenvolvimento de um produto fitoterápico. Rev Bras Farmacogn. 2008; 18: 744747.
Santos SC. Caracterização cromatográfica de extratos medicinais de guaco: Mikania laevigata Shultz Bip. Ex Baker e $M$. glomerata Sprengel. e ação de $M$. laevigata na inflamação alérgica pulmonar. Itajaí. Dissertação de Mestrado. Universidade do Vale do Itajaí, SC. Brasil. 2005.

Silva FR. 2007. Genotoxicidade ocasionada pelas folhas do fumo (Nicotina tabacum) expostos ou não a agrotóxicos, em Cantareus aspersus. Dissertação de Mestrado. Universidade Federal do Rio Grande do Sul. Porto Alegre, RG. Disponível em: http://www.lume.ufrgs.br/bitstream/handle/10183/10 963/000600913.pdf? sequence $=1$. Acesso em Dezembro de 2011.

Simões CMO, Schenkel EP, Gosmann G, Mello JCP, Mentz LA, Petrovick PR. Farmacognosia: da planta ao medicamento. $6^{\circ}$ edição. UFRGS. 1104p. 2010.

Singh A, Singh DK, Mishra TN, Agarwal RA. Molluscicides of plant origin. Biol Agric Hortic. 1996; 13: 205-252.

Souza CP, Mendens MN, Jannotti-Passos LK, Pereira JP. O uso da casca da castanha do caju, Anacardium occidentale como moluscicida alternativo. Rev Inst Med Tropical. São Paulo, 1992; 34: 459-466.

Taleb-Contini SH, Santos PA, Veneziani RCS, Pereira MAS, França SC, Lopes NP, et al. Diferences in secondary metabolites from leaf extracts of Mikania glomerata Sprengel obtained by micropropagation and cuttings. Rev Bras Farmacog. 2006; 16: 596-598.

World Health Organization. Specifications and evaluations for public health pesticides. Bull World Health Organ. 24p. 2002.

World Health Organization. Reports of The Scientific Group On Plant Moluscicide. Bull World Health Organ. Geneve, 61: 927-929. 1983.

World Health Organization. Memoranda: Molluscicide screening and evaluation. Bull World Health Organ. 33: 567-576. 1965.

World Health Organization. Quality control methods for medicinal plant materials. WHO/Pharm/92.559, 1992. p. 33-35.

Xavier V B, Borba H R, Brandolini SVPB. Atividade biológica de Solanum lycocarpum (Solanaceae) procedente de regiões fitogeográficas distintas sobre Biomphalaria glabrata (Planorbidae). Rev Bras Zooc. 2010; 12: 43-49.
Received: June 12, 2012 ; Accepted: November 25, 2013. 